\title{
Diversity and prevalence of gastrointestinal parasites in seven non-human primates of the Taï National Park, Côte d'Ivoire
}

\author{
Roland Yao Wa Kouassi ${ }^{1,2,4,6, *}$, Scott William McGraw ${ }^{3}$, Patrick Kouassi Yao ${ }^{1}$, Ahmed Abou-Bacar ${ }^{4,6}$, \\ Julie Brunet ${ }^{4,5,6}$, Bernard Pesson ${ }^{4}$, Bassirou Bonfoh ${ }^{2}$, Eliezer Kouakou N'goran ${ }^{1}$, \\ and Ermanno Candolfi, ${ }^{4,6}$ \\ ${ }^{1}$ Unité de Formation et de Recherche Biosciences, Université Félix Houphouët Boigny, 22 BP 770, Abidjan 22, Côte d'Ivoire \\ 2 Centre Suisse de Recherches Scientifiques en Côte d'Ivoire, 01 BP 1303, Abidjan 01, Côte d'Ivoire \\ 3 Department of Anthropology, Ohio State University, 4064 Smith Laboratory, 174 West 18th Avenue, Columbus, Ohio 43210, USA \\ 4 Laboratoire de Parasitologie et de Mycologie Médicale, Plateau Technique de Microbiologie, Hôpitaux Universitaires de Strasbourg, \\ 1 rue Koeberlé, 67000 Strasbourg, France \\ 5 Laboratoire de Parasitologie, Faculté de Pharmacie, Université de Strasbourg, 74 route du Rhin, 67401 Illkirch cedex, France \\ 6 Institut de Parasitologie et de Pathologie Tropicale, EA 7292, Fédération de Médecine Translationnelle, Université de Strasbourg, \\ 3 rue Koeberlé, 67000 Strasbourg, France
}

Received 25 July 2014, Accepted 14 January 2015, Published online 27 January 2015

\begin{abstract}
Parasites and infectious diseases are well-known threats to primate populations. The main objective of this study was to provide baseline data on fecal parasites in the cercopithecid monkeys inhabiting Côte d'Ivoire's Taï National Park. Seven of eight cercopithecid species present in the park were sampled: Cercopithecus diana, Cercopithecus campbelli, Cercopithecus petaurista, Procolobus badius, Procolobus verus, Colobus polykomos, and Cercocebus atys. We collected 3142 monkey stool samples between November 2009 and December 2010. Stool samples were processed by direct wet mount examination, formalin-ethyl acetate concentration, and MIF (merthiolate, iodine, formalin) concentration methods. Slides were examined under microscope and parasite identification was based on the morphology of cysts, eggs, and adult worms. A total of 23 species of parasites was recovered including 9 protozoa (Entamoeba coli, Entamoeba histolytica/dispar, Entamoeba hartmanni, Endolimax nana, Iodamoeba butschlii, Chilomastix mesnili, Giardia sp., Balantidium coli, and Blastocystis sp.), 13 nematodes (Oesophagostomum sp., Ancylostoma sp., Anatrichosoma sp., Capillariidae Gen. sp. 1, Capillariidae Gen. sp. 2, Chitwoodspirura sp., Subulura sp., spirurids [cf Protospirura muricola], Ternidens sp., Strongyloides sp., Trichostrongylus sp., and Trichuris sp.), and 1 trematode (Dicrocoelium sp.). Diversity indices and parasite richness were high for all monkey taxa, but C. diana, C. petaurista, C. atys, and C. campbelli exhibited a greater diversity of parasite species and a more equitable distribution. The parasitological data reported are the first available for these cercopithecid species within Taï National Park.
\end{abstract}

Key words: Gastrointestinal parasites, Non-human primates, Prevalence, Côte d'Ivoire.

Résumé - Diversité et prévalence des parasites gastrointestinaux chez sept espèces de primates non-humains
du Parc National de Taï en Côte d'Ivoire. Les maladies parasitaires et infectieuses sont des menaces très connues
pour les populations de primates. L'objectif principal de cette étude était de fournir des données de base sur les
parasites intestinaux des primates non-humains du Parc National de Taï en Côte d'Ivoire. Sept des huit espèces de
cercopithécidés vivant dans le parc ont été échantillonnées : Cercopithecus diana, Cercopithecus campbelli,
Cercopithecus petaurista, Procolobus badius, Procolobus verus, Colobus polykomos and Cercocebus atys. Nous
avons collecté 3142 échantillons de selles de singes de novembre 2009 à décembre 2010. Les échantillons de
selles ont été traités par la technique d'examen direct, les méthodes de concentration formol-éthyl acétate et MIF
(merthiolate, iode, formol). Les lames ont été examinées au microscope et l'identification des parasites a été basée
sur la morphologie des kystes, des œufs et des vers adultes. Au total, 23 espèces de parasites ont été trouvées,
dont 9 protozoaires (Entamoeba coli, Entamoeba histolytica/dispar, Entamoeba hartmanni, Endolimax nana,

\footnotetext{
*Corresponding author: kwaroland@yahoo.fr
}

This is an Open Access article distributed under the terms of the Creative Commons Attribution License (http://creativecommons.org/licenses/by/4.0), which permits unrestricted use, distribution, and reproduction in any medium, provided the original work is properly cited. 
Iodamoeba butschlii, Chilomastix mesnili, Giardia sp., Balantidium coli et Blastocystis sp.), 13 nématodes (Oesophagostomum sp., Ancylostoma sp., Anatrichosoma sp., Capillariidae Gen. sp. 1, Capillariidae Gen. sp. 2, Chitwoodspirura sp., Subulura sp., Spiruridae [cf. Protospirura muricola], Ternidens sp., Strongyloides sp., Trichostrongylus sp. et Trichuris sp.), et un trématode (Dicrocoelium sp.). Lindice de diversité et la richesse parasitaire étaient élevés pour tous les taxa de singes, mais $C$. diana, C. petaurista, $C$. atys and C. campbelli ont enregistré une plus grande diversité et une distribution plus équitable des espèces de parasites. Les données parasitologiques que nous rapportons sont les premières disponibles pour ces espèces de singes du Parc National de Taï.

\section{Introduction}

Côte d'Ivoire's Taï National Park (TNP) is the last remaining major intact block of primary forest in West Africa. It was declared a UNESCO World Heritage Site in 1982 due to exceptional richness in fauna and flora. Indeed, based on several criteria including species diversity, endemism, presence of rare species and/or endangered and critical habitats, the TNP is considered a priority for the conservation of mammals, birds, amphibians, and invertebrates in West Africa [13]. The park contains fauna typical of West African forests, including eight monkey species: Diana monkey (Cercopithecus diana), Campbell's monkey (Cercopithecus campbelli), lesser spot-nosed monkey (Cercopithecus petaurista), putty-nosed monkey (Cercopithecus nictitans), red colobus monkey (Procolobus badius), olive colobus monkey (Procolobus verus), western black and white colobus monkey (Colobus polykomos), and sooty mangabey (Cercocebus atys). Since 1989, multiple aspects of behavior, ecology, and anatomy of this primate community have been subjected to investigation by members of the Taï Monkey Project (TMP) including mixed-species associations, feeding, ranging, positional behavior, vocalization, sociality, anti-predator adaptations, and conservation [44]. To date, no studies have been undertaken on the gastrointestinal parasites of monkeys in this region.

Many protozoa and helminths are known to infect primate groups [69]. Parasites and infectious diseases have become a major concern in conservation biology, in part because they can trigger or accelerate population declines [3]. Many studies have documented the gastrointestinal parasites of wild populations of African primates [18, 19, 26, 30, 40, 45, 60]. In recent years, several infectious diseases have been recorded in primate groups followed by researchers from monkey and chimpanzee projects in Taï National Park [16, 21, 32, 34, 37]. However, the diversity and abundance of gastrointestinal parasites in the cercopithecids inhabiting forests within West Africa's Upper Guinea region have yet to be examined systematically. In this study, we identify and quantify the prevalence of gastrointestinal parasites in seven sympatric primates ranging within Côte d'Ivoire's Taï National Park. Our report on parasite diversity constitutes the first parasite data for cercopithecid primates within this tropical region.

\section{Materials and methods}

\section{Study site}

The study was conducted in Taï National Park in southwestern Côte d'Ivoire ( $6^{\circ} 20 \mathrm{~N}-5^{\circ} 10 \mathrm{~N}$ and $\left.4^{\circ} 20 \mathrm{~W}-6^{\circ} 50 \mathrm{~W}\right)$.
The park is the last remaining major block of primary forest in West Africa. It covers approximately 457,000 ha of rainforest and is bordered in the North by the N'zo Wildlife Reserve (79,000 ha) (Fig. 1). Annual rainfall averages $1800 \mathrm{~mm}$ and daily temperatures average $24{ }^{\circ} \mathrm{C}$. The climate is characterized by four seasons: two rainy seasons (March-June and SeptemberNovember) and two dry seasons (December-February and July-August). The study site has been described in detail elsewhere [42]. The seven cercopithecid taxa investigated are Cercocebus atys, Cercopithecus campbelli, Cercopithecus diana, Cercopithecus petaurista, Colobus polykomos, Procolobus badius, and Procolobus verus. Since 1991, these monkeys have been under continuous study in Taï National Park and at least one (in some cases three) social group of each species is fully habituated to human observers [31, 44]. With one exception, the home ranges of all monkey groups sampled are contained within the $2 \mathrm{~km}^{2}$ core area of the Taï Monkey Project (McGraw et al. 2007). The home range of Cercocebus atys is significantly larger than those of the other species and extends beyond the primary study grid. The relationships between locomotion and habitat use in these monkey taxa have been described elsewhere [42, 43].

\section{Field and laboratory procedures}

Between November 2009 and December 2010, we collected fecal samples from all monkey taxa during dawn to dusk (06:30-18:00). Over the course of the 13 month sampling period, we collected 3142 fecal samples from the seven primate species. Table 1 provides information on the demographic composition of each monkey species. To avoid contamination, fecal samples were collected from the center of each fecal mass immediately following defecation. Immediately upon returning to the field station located adjacent to the primary study grid, samples were placed individually in $20.0 \mathrm{~mL}$ sterile vials in $10 \%$ formalin solution in order to avoid contamination. Each sample was studied by wet mount examination, Ritchie method modified using Formalin-ethyl acetate concentration [15, 35, 73], to diagnose helminths and protozoa; additionally, the merthiolateiodine-formalin concentration (MIFC) technique was used for better identification of intestinal protozoa [8]. Eggs and cysts were detected under a microscope (Leica DM2000 LED) equipped with a digital camera control unit (Leica DFC450). Parasites were identified on the basis of egg color, shape, contents, size, larvae, and cysts [24, 28]. Measurements were made to the nearest $0.1 \mu \mathrm{m}$ using a micrometer integrated into the digital camera. Representatives of each parasite were photographed. 


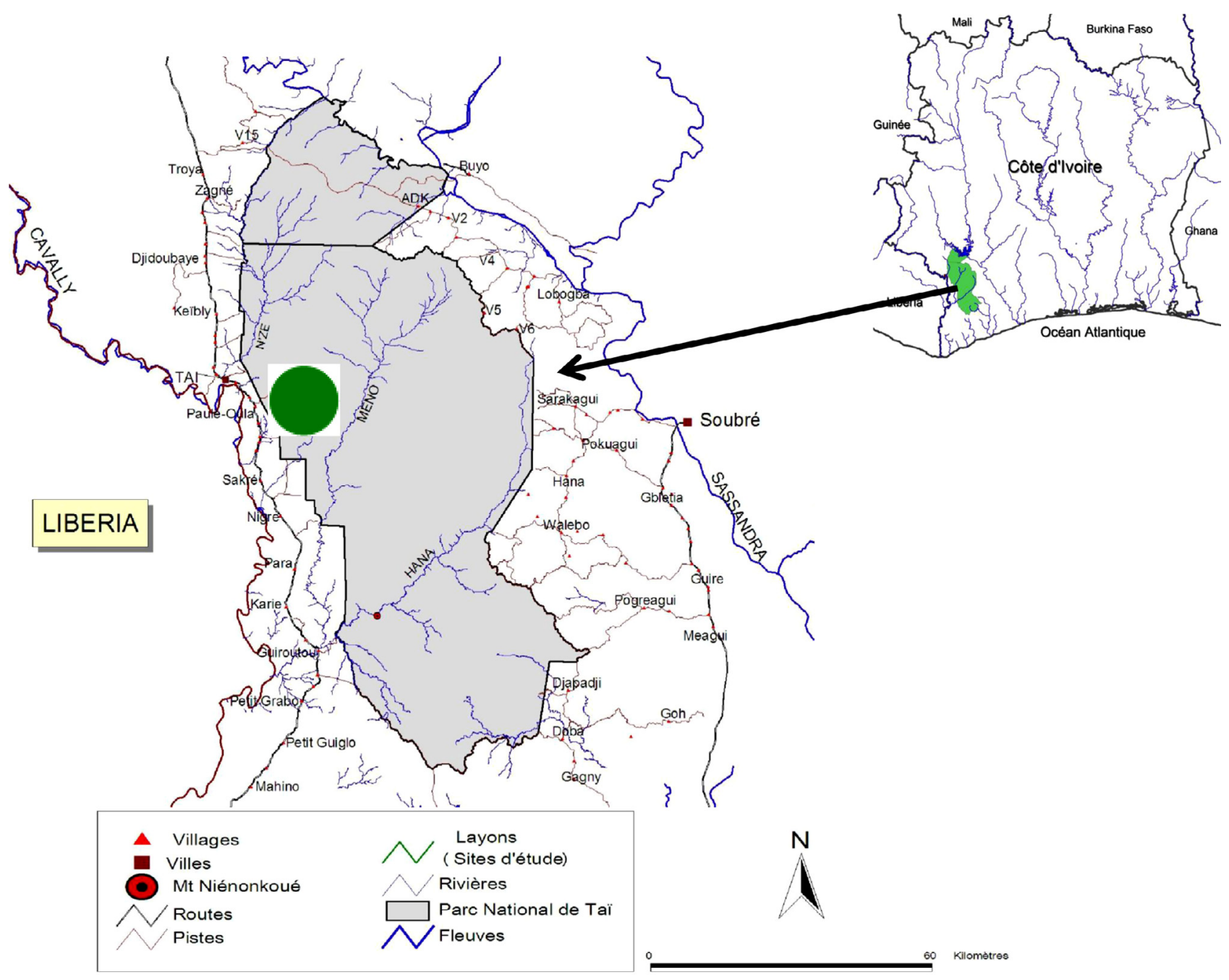

Figure 1. Location of the study area in Taï National Park, Côte d'Ivoire Green dot = Study area.

Table 1. Composition of monkey groups.

\begin{tabular}{|c|c|c|c|c|c|c|c|}
\hline & $\begin{array}{c}\text { Cercocebus } \\
\text { atys }\end{array}$ & $\begin{array}{c}\text { Procolobus } \\
\text { badius }\end{array}$ & $\begin{array}{c}\text { Colobus } \\
\text { polykomos }\end{array}$ & $\begin{array}{c}\text { Procolobus } \\
\text { verus }\end{array}$ & $\begin{array}{c}\text { Cercopithecus } \\
\text { campbelli }\end{array}$ & $\begin{array}{c}\text { Cercopithecus } \\
\text { petaurista }\end{array}$ & $\begin{array}{l}\text { Cercopithecus } \\
\text { diana }\end{array}$ \\
\hline Adult Male & 6 & 11 & 2 & 2 & 1 & 1 & 1 \\
\hline Adult Female & 33 & 30 & 2 & 2 & 7 & 8 & 9 \\
\hline Subadult Male & 18 & 3 & 2 & 2 & 2 & 3 & 2 \\
\hline $\begin{array}{l}\text { Subadult } \\
\text { Female }\end{array}$ & 19 & 2 & 1 & - & 1 & 1 & 6 \\
\hline Juvenile Male & 21 & - & 1 & - & 2 & 2 & 1 \\
\hline $\begin{array}{l}\text { Juvenile } \\
\text { Female }\end{array}$ & 28 & 2 & - & - & 3 & 2 & 3 \\
\hline Infant & - & 3 & - & 1 & 1 & 2 & 3 \\
\hline Total & 125 & 51 & 8 & 7 & 16 & 19 & 25 \\
\hline
\end{tabular}

\section{Statistical analysis}

Data were entered into an Excel spreadsheet and transferred into Stata version 11 (StataCorp.; College Station, United States of America). Fisher's exact test was used to compare parasite prevalence between monkey taxa. $P$ values below 0.05 were considered as significant. The Shannon diversity index was used to measure diversity, abundance, and equitability of parasite species present in the monkey community. 
Table 2. Parasite richness and Shannon's diversity index.

\begin{tabular}{|c|c|c|c|c|}
\hline Monkey species & Number of parasites & Parasite richness $(\%)$ & Diversity index $(H)$ & Equitability index $(E)$ \\
\hline \multicolumn{5}{|c|}{ Helminths and protozoa } \\
\hline C. atys & 20 & $20 / 23(86.96 \%)$ & 2.251 & 0.718 \\
\hline C. campbelli & 19 & $19 / 23(82.61 \%)$ & 2.173 & 0.7136 \\
\hline C. diana & 19 & $19 / 23(82.61 \%)$ & 2.446 & 0.8035 \\
\hline C. petaurista & 20 & $20 / 23(86.96 \%)$ & 2.387 & 0.7841 \\
\hline P. badius & 15 & $15 / 23(65.22 \%)$ & 1.574 & 0.5812 \\
\hline C. polykomos & 15 & $15 / 23(65.22 \%)$ & 1.3 & 0.4498 \\
\hline P. verus & 17 & $17 / 23(73.91 \%)$ & 1.343 & 0.4647 \\
\hline \multicolumn{5}{|c|}{ Helminths } \\
\hline C. atys & 11 & $11 / 14(78.57 \%)$ & 1.902 & 0.7934 \\
\hline C. campbelli & 10 & $10 / 14(71.43 \%)$ & 1.723 & 0.7484 \\
\hline C. diana & 10 & $10 / 14(71.43 \%)$ & 1.887 & 0.8197 \\
\hline C. petaurista & 11 & $11 / 14(78.57 \%)$ & 1.738 & 0.7246 \\
\hline P. badius & 6 & $6 / 14(42.86 \%)$ & 1.092 & 0.6097 \\
\hline C. polykomos & 6 & $6 / 14(42.86 \%)$ & 0.8384 & 0.4372 \\
\hline$P$ verus & 8 & $8 / 14(57.14 \%)$ & 0.9013 & 0.4203 \\
\hline \multicolumn{5}{|c|}{ Protozoa } \\
\hline C. atys & 9 & 9/9 (100\%) & 0.8157 & 0.3712 \\
\hline C. campbelli & 9 & $9 / 9(100 \%)$ & 1.946 & 0.8858 \\
\hline C. diana & 9 & $9 / 9(100 \%)$ & 2.005 & 0.9124 \\
\hline C. petaurista & 9 & $9 / 9(100 \%)$ & 1.991 & 0.9063 \\
\hline P. badius & 9 & $9 / 9(100 \%)$ & 1.832 & 0.8337 \\
\hline C. polykomos & 9 & $9 / 9(100 \%)$ & 1.859 & 0.8462 \\
\hline P. verus & 9 & 9/9 (100\%) & 1.816 & 0.8264 \\
\hline
\end{tabular}

\section{Results}

\section{Parasite species of non-human primates in Taï forest}

Nine protozoa (Fig. 2) and 14 helminths (Fig. 3) were detected. All seven non-human primate species were infected by 9 protozoa (Entamoeba coli, E. histolytica/dispar, E. hartmanni, Endolimax nana, Iodamoeba butschlii, Chilomastix mesnili, Balantidium coli, Blastocystis sp., and Giardia sp.) and 5 helminths (Oesophagostomum sp., Ancylostoma sp., Capillariidae Gen. sp. 2, Strongyloides sp., and Trichuris sp.). The remaining nine helminths were distributed in the Taï monkeys as follows: Capillariidae Gen. sp. 1 and Ternidens sp. were found in C. campbelli, C. diana, and C. petaurista. Subulura sp. was detected in C. campbelli and C. diana. Protospirura muricola was identified in C. petaurista and C. diana. Anatrichosoma sp. and Chitwoodspirura sp. were revealed only in C. petaurista. Trichostrongylus sp. was detected in C. campbelli and P. verus. Dicrocoelium sp. was found in P. badius, C. polykomos, and $P$. verus. Strongyloides stercoralis was identified in C. campbelli, C. diana, C. petaurista, and P. verus.

\section{Diversity index and prevalence of parasite species in Taï monkeys}

A total of 23 species of parasites were found in the seven monkey species at Taï. $C$. atys and $C$. petaurista were infected by 20 gastrointestinal parasites $(86.96 \%)$. Nineteen species of parasites $(82.61 \%)$ were detected in C. campbelli and C. diana. The lowest number of parasite species was recorded in $P$. badius and $C$. polykomos with 15 parasites $(65.22 \%)$.
For all parasites, species diversity as reflected by Shannon's diversity index and equitability was high in all monkeys. However, the highest diversity and equitability indices were recorded in $C$. diana $(H=2.394 ; E=0.8132), C$. petaurista $(H=2.364 ; \quad E=0.7901), \quad C e r c o c e b u s$ atys $(H=2.191$; $E=0.7315)$, and $C$. campbelli $(H=2.159 ; E=0.7332)$. For the helminths, Shannon's index and equitability was higher with more equitable distribution in $C$. diana, C. petaurista, and $C$. campbelli. Cercocebus atys exhibit higher values $(H=1.902 ; E=0.7934)$. Protozoa have higher Shannon index and high equitable distribution in $C$. campbelli, $C$. diana, $C$. petaurista, P. badius, C. polykomos, and $P$. verus. Cercocebus atys exhibit lower values $(H=0.8157 ; E=0.3712)$ (Table 2$)$.

The majority of gastrointestinal parasites found in the Tai primates exhibit relatively high abundances. Entamoeba coli (91.96\%), Balantidium coli (60.3\%), Iodamoeba butschlii (53.37\%), and E. histolytica/dispar (53.27\%) were the most prevalent protozoa, whereas the predominant prevalent helminths were Trichuris sp. (93.02\%), Oesophagostomum sp. (79.9\%), Strongyloides sp. (74.42\%) and Ancylostoma sp. (73.87\%).

Considering all parasites, there are significant differences in prevalence among the seven monkey species $(P<0.0001)$ (Table 3). Prevalence of individual parasites was compared only among monkey taxa infected by them and in most cases, there were statistically significant differences. Anatrichosoma sp. was detected in feces of C. atys (5.03\%) and C. petaurista (3.18\%). The difference in the prevalence of Anatrichosoma sp. was not statistically significant $(P=0.442)$. Differences in the prevalence of Capillariidae Gen. sp. 1 were significant between C. campbelli (13.48\%), C. petaurista (3.18\%), and C. diana $(11.7 \%),(P=0.004)$. Eggs of Subulura sp. were 
Table 3. Prevalence (\%) of gastrointestinal parasites in Taï forest monkeys.

\begin{tabular}{|c|c|c|c|c|c|c|c|c|c|c|}
\hline & & $\begin{array}{c}\text { C. atys } \\
n=199\end{array}$ & $\begin{array}{c}\text { C. campbelli } \\
n=178\end{array}$ & $\begin{array}{l}\text { C. diana } \\
n=171\end{array}$ & $\begin{array}{c}\text { C. petaurista } \\
n=157\end{array}$ & $\begin{array}{l}\text { P. badius } \\
n=245\end{array}$ & $\begin{array}{l}\text { C. polykomos } \\
n=125\end{array}$ & $\begin{array}{l}P . \text { verus } \\
n=129\end{array}$ & \multirow[b]{2}{*}{$P$-value } & \multirow[b]{2}{*}{ Mean size $(\mu \mathrm{m}) \pm 95 \% \mathrm{CI}(\mu \mathrm{m})$} \\
\hline & & \multicolumn{7}{|c|}{ Prevalence } & & \\
\hline \multirow[t]{14}{*}{ Helminths } & Anatrichosoma sp. & 5.03 & 0 & 0 & 3.18 & 0 & 0 & 0 & $<10^{-3}$ & $72.33 \times 52.79 \pm 3.61 \times 4.03$ \\
\hline & Ancylostoma sp. & 73.87 & 46.07 & 38.01 & 37.58 & 13.11 & 7.2 & 4.65 & $<10^{-3}$ & $65.64 \times 41.4 \pm 4.44 \times 2.31$ \\
\hline & Capillariidae Gen. sp. 1 & 0 & 13.48 & 11.7 & 3.18 & 0 & 0 & 0 & $<10^{-3}$ & $48.94 \times 23.55 \pm 2.05 \times 0.99$ \\
\hline & Capillariidae Gen. sp. 2 & 20.1 & 10.11 & 12.87 & 6.37 & 1.64 & 4 & 3.1 & $<10^{-3}$ & $57.73 \times 23.88 \pm 3.1 \times 1.08$ \\
\hline & Chitwoodspirura $\mathrm{sp}$. & 0 & 0 & 0 & 1.27 & 0 & 0 & 0 & $<10^{-3}$ & $40.4 \times 23.8 \pm 0.2 \times 0.18$ \\
\hline & Oesophagostomum sp. & 79.9 & 56.18 & 25.15 & 30.57 & 15.92 & 8.8 & 4.65 & $<10^{-3}$ & $72.61 \times 41.54 \pm 1.61 \times 2.78$ \\
\hline & Subulura sp. & 30.15 & 0.56 & 2.92 & 0 & 0 & 0 & 0 & $<10^{-3}$ & $41.68 \times 33.84 \pm 0.7 \times 0.3$ \\
\hline & Strongyloides sp. & 33.17 & 21.35 & 21.64 & 21.02 & 31.84 & 14.4 & 74.42 & $<10^{-3}$ & $51.79 \times 31.94 \pm 4.27 \times 2$ \\
\hline & Strongyloides stercoralis & 7.04 & 8.99 & 2.34 & 4.46 & 0 & 0 & 17.83 & $<10^{-3}$ & $254.7 \times 17.2 \pm 7.41 \times 3.03$ \\
\hline & $\begin{array}{l}\text { Spirurid (cf. Protospirura } \\
\text { muricola) }\end{array}$ & 56.78 & 0 & 9.36 & 4.46 & 0 & 0 & 0 & $<10^{-3}$ & $54.97 \times 37.37 \pm 2.06 \times 3.43$ \\
\hline & Ternidens sp. & 9.55 & 8.43 & 2.92 & 2.55 & 0 & 0 & 0 & $<10^{-3}$ & $90.08 \times 50.31 \pm 3.06 \times 2.6$ \\
\hline & Trichuris sp. & 11.06 & 22.47 & 8.77 & 18.47 & 73.77 & 75.2 & 93.02 & $<10^{-3}$ & $57.78 \times 26.7 \pm 2.91 \times 1.9$ \\
\hline & Trichostrongylus sp. & 0 & 2.25 & 0 & 0 & 0 & 0 & 5.43 & $<10^{-3}$ & $84.75 \times 44.3 \pm 3.77 \times 0.9$ \\
\hline & Dicrocoelium $\mathrm{sp}$. & 36.68 & 0 & 0 & 0 & 15.51 & 32.8 & 3.88 & $<10^{-3}$ & $40.15 \times 22.28 \pm 1.5 \times 0.87$ \\
\hline \multirow[t]{9}{*}{ Protozoa } & Entamoeba coli & 91.96 & 58.43 & 60.82 & 79.62 & 59.43 & 49.6 & 61.24 & $<10^{-3}$ & $17.3 \pm 2.1$ \\
\hline & Entamoeba histolytica/dispar & 53.27 & 28.09 & 28.07 & 43.95 & 23.77 & 13.6 & 29.46 & $<10^{-3}$ & $14.2 \pm 1.2$ \\
\hline & Entamoeba hartmanni & 34.17 & 25.28 & 25.73 & 45.86 & 26.64 & 23.2 & 24.81 & $<10^{-3}$ & $10.3 \pm 0.8$ \\
\hline & Endolimax nana & 16.58 & 24.72 & 26.9 & 36.31 & 17.62 & 12.8 & 13.95 & $<10^{-3}$ & $6.27 \times 4.65 \pm 0.86 \times 0.44$ \\
\hline & Iodamoeba butschlii & 38.69 & 53.37 & 49.12 & 48.41 & 36.89 & 24.8 & 38.76 & $<10^{-3}$ & $14.26 \times 10.37 \pm 0.77 \times 1.02$ \\
\hline & Balantidium coli & 60.3 & 4.49 & 4.68 & 6.37 & 8.61 & 4 & 11.63 & $<10^{-3}$ & $44.40 \times 40.44 \pm 3.26 \times 4.28$ \\
\hline & Chilomastix mesnili & 32.66 & 14.61 & 26.9 & 31.21 & 19.67 & 10.4 & 20.93 & $<10^{-3}$ & $8.6 \times 5.4 \pm 0.83 \times 1.1$ \\
\hline & Giardia sp. & 28.64 & 15.73 & 14.62 & 19.11 & 7.38 & 5.6 & 9.3 & $<10^{-3}$ & $11.96 \times 8.99 \pm 0.7 \times 0.9$ \\
\hline & Blastocystis sp. & 37.19 & 7.3 & 9.36 & 9.55 & 4.92 & 4 & 8.53 & $<10^{-3}$ & $8.41 \times 5.5 \pm 0.82 \times 0.53$ \\
\hline
\end{tabular}




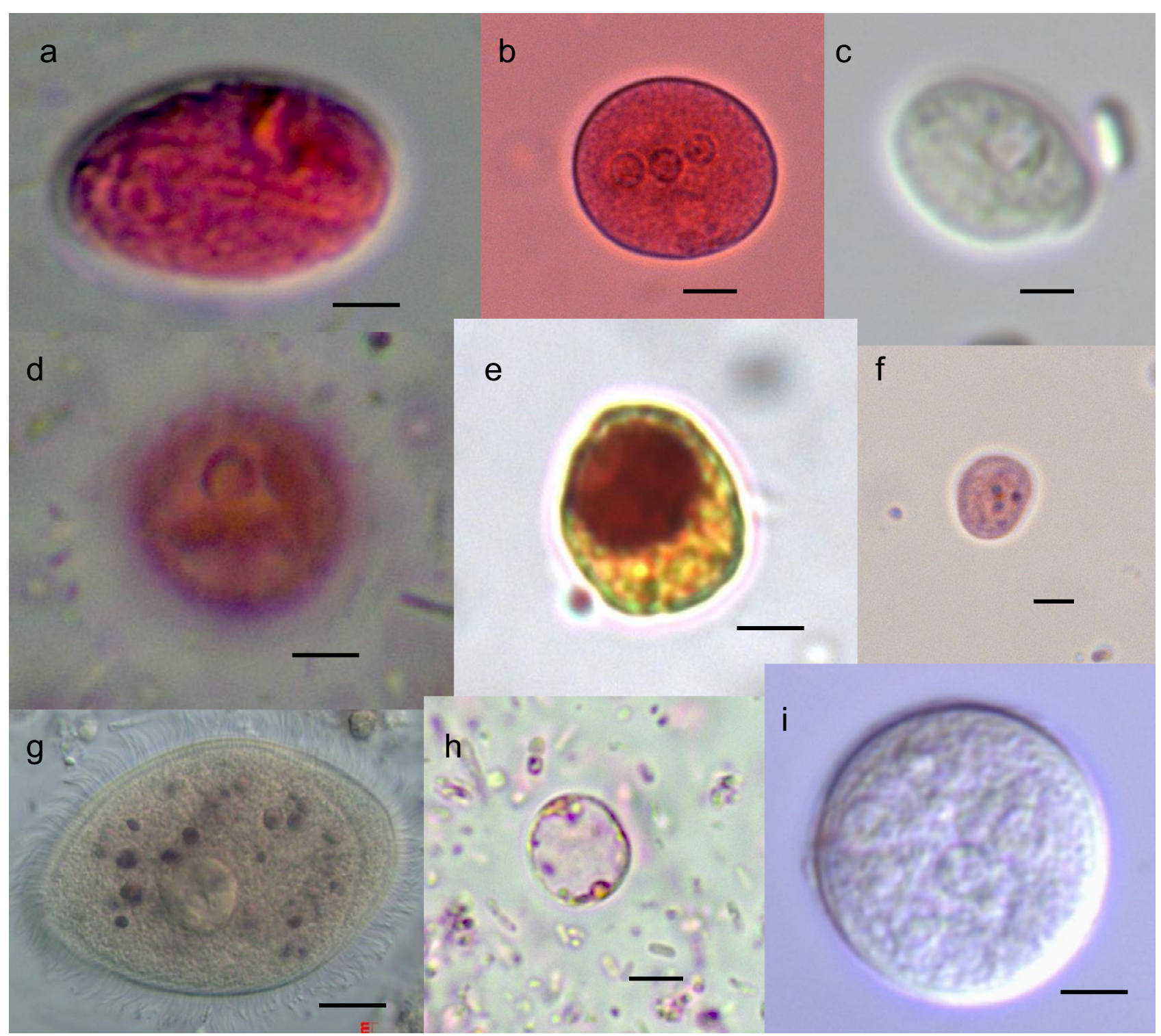

Figure 2. (a) Giardia sp. (cyst), (b) Entamoeba hartmanni (cyst), (c) Chilomastix mesnili (cyst), (d) Entamoeba histolytica/dispar (cyst), (e) Iodameoba butschlii (cyst), (f) Endolimax nana (cyst), (g) Balantidium coli (trophozoites), (h) Blastocystis sp. (cyst), (i) Entamoeba coli (cyst). Scale bars: $\mathrm{a}-\mathrm{i}=5 \mu \mathrm{m}$.

detected in C. atys (30.15\%), C. campbelli $(0.56 \%)$, and C. diana $(2.92 \%)$. Differences in the prevalence of Subulura sp. were statistically significant $(P<0.0001)$. Differences in the prevalence of Protospirura muricola between $C$. atys (56.78\%), C. petaurista (4.46\%), and C. diana (9.36\%) were significant $(P<0.0001)$. Strongyloides stercoralis was found in feces of P. verus $(17.83 \%), C$. atys $(7.04 \%), C$. campbelli (8.99\%), C. petaurista (4.46\%), and C. diana (2.34\%). Differences in the prevalence of Strongyloides stercoralis were significant $(P<0.0001)$. Differences in the prevalence of Trichostrongylus sp. between C. campbelli (2.25\%) and $P$. verus $(5.43 \%)$ were not significant $(P=0.216)$. Dicrocoeliid eggs were identified in $C$. atys, $C$. polykomos, and $C$. verus. Differences in the prevalence of Dicrocoelium sp. in C. atys (36.68\%), C. polykomos (32.8\%), P. badius (15.51\%), and
P. verus $(3.88 \%)$ were significant $(P<0.0001)$. Ternidens sp. was found in C. atys $(9.55 \%), C$. campbelli $(8.43 \%)$, C. petaurista $(2.55 \%)$, and $C$. diana $(2.92 \%)$. Differences in the prevalence were significant $(P<0.0001)$.

\section{Discussion}

Our analyses reveal significant richness and diversity of gastrointestinal parasites in the cercopithecid monkeys of Taï National Park. The diversity indices demonstrate considerable species diversity and an equitable distribution of gastrointestinal parasites found in these monkeys. By comparison, 21 gastrointestinal parasites were identified in Kenya's Tana River mangabey [41] and 14 parasite species were identified in 


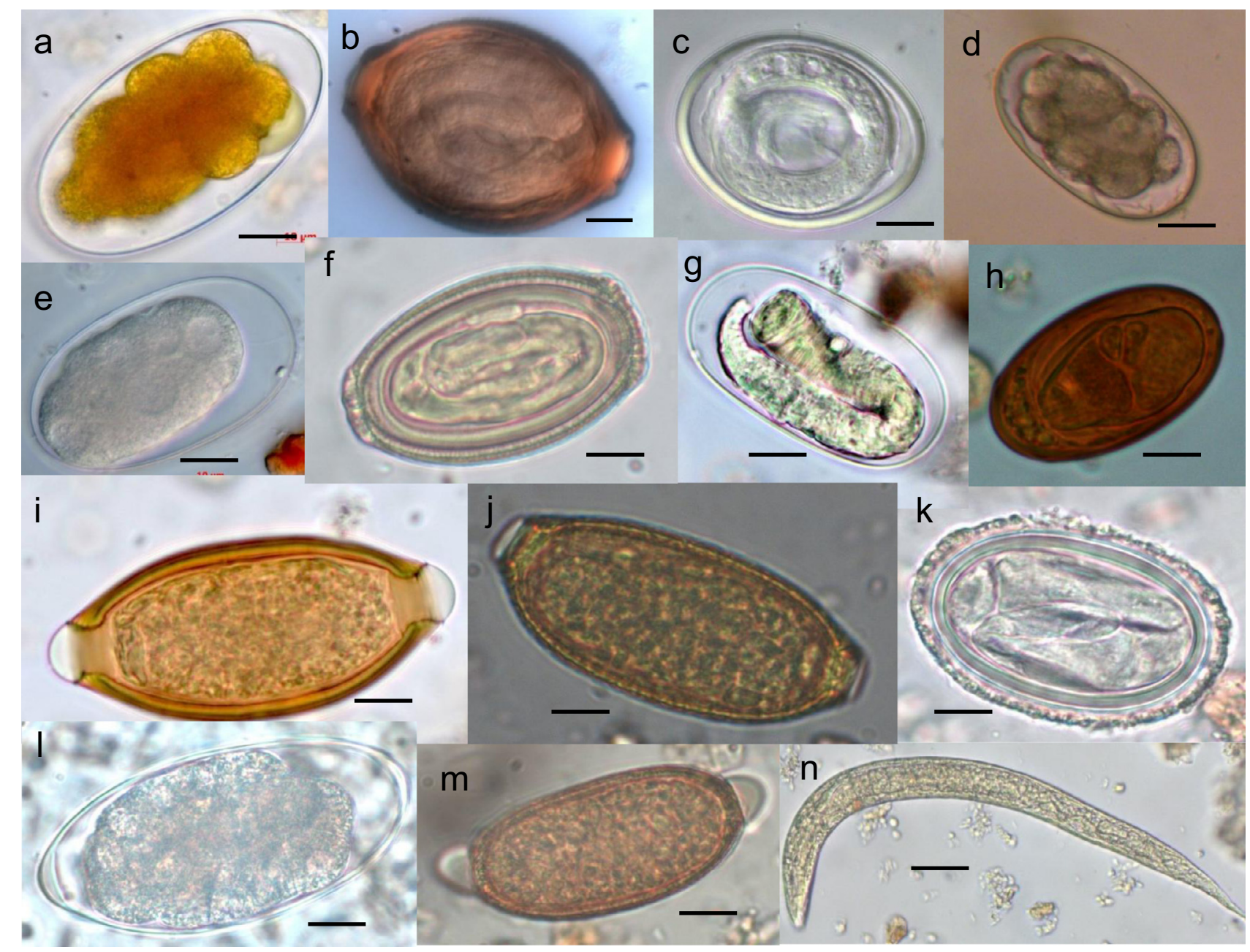

Figure 3. (a) Ternidens sp., (b) Anatrichosoma sp., (c) Subulura sp., (d) Ancylostoma sp., (e) Oesophagostomum sp., (f) Chitwoodspirura sp., (g) Strongyloides sp., (h) Dicrocoelium sp., (i) Trichuris sp., (j) Capillariidae Gen. sp. 1, (k) Protospirura muricola, (1) Trichostrongylus sp., (m) Capillariidae Gen. sp. 2, (n) Strongyloides stercoralis (rhabditoid larva). Scale bars: $\mathrm{a}-\mathrm{m}=10 \mu \mathrm{m} ; \mathrm{n}=25 \mu \mathrm{m}$.

monkeys of Uganda's Kibale Forest [18, 19]. Thirteen parasite species were found in Mahale National Park of Tanzania [30] and 12 species were found in Rubondo Island National Park of Tanzania [57]. Based on available data, the total of 23 gastrointestinal parasites recorded in the Taï monkeys represents the greatest parasite richness documented to date for African nonhuman primates.

A large majority of intestinal protozoa are reported with high prevalence in the Taï monkeys. These amoebae are common in non-human primates which are a well-known reservoir for gastrointestinal parasites due to a direct life cycle, and transmission by various forms of contact [56]. Amoebae were found in all seven primate taxa and relatively high prevalence was recorded. Several studies have highlighted amoebae in African non-human primates [18, 19, 26, 57]. Entamoeba coli, E. histolytica/dispar, and Iodamoeba butschlii had the highest prevalence in the Taï monkeys.

Balantidium coli is widely distributed in primates. B. coli is the only pathogenic ciliate and is the largest protozoa that parasitizes humans, but the risk for non-human primates has not been demonstrated [20]. We reported relatively low prevalence of B. coli in the Taï monkeys (11.63 to 4\%) except for Cercocebus atys (60.3\%). Survey of another African cercopithecid - the Tana River mangabey (Cercocebus galeritus) - revealed a lower prevalence of $B$. coli [41] than in our study. However, high prevalence was recorded in baboons of Mole National Park, Ghana [60].

Several studies have described the presence of Blastocystis sp. in wildlife, livestock, and humans [6, 55, 65, 71, 72]. A large number of morphological cell types have been described and the three major forms are vacuolar, granular, and amoeboid [9, 66, 74]. Nevertheless, Blastocystis sp. morphology is not well understood [12]. On the basis of molecular analysis of the ssrRNA gene, eight distinct subtypes (STs) ST1, ST2, ST3, ST4, ST5, ST8, ST13, and ST15 were isolated from non-human primates [1]. Vacuolar forms predominated in feces of the Taï monkeys.

Giardia sp. is a parasitic protozoan pathogen that infects the small and large intestines of a broad range of mammals including non-human primates. G. duodenalis ranges in 
clinical severity from asymptomatic to highly pathogenic. Trophozoites pass through the small intestine; they encyst and are then excreted with feces. Monkeys are infected by ingestion of Giardia cysts in food or water contaminated by feces [23]. High prevalence of Giardia sp. has been reported in wild Colobus in Ghana [67]. In many cases, high prevalence of Giardia infection has been recorded in primates living in disturbed forest or in forest fragments [61, 67]. Our findings demonstrate the relatively high prevalence of Giardia sp. in monkeys living in undisturbed forest. Molecular analyses will clarify the genotypes (assemblages) of Giardia sp. in these monkey populations.

Oesophagostomum sp. is one of the most common parasites identified in African primates [5, 11, 18, 19, 41, 60]. In humans, Oesophagostomum causes esophagostomosis resulting in the formation of granulomas, caseous lesions, or abscesses in intestinal walls; however, great apes are known to develop nodular esophagostomosis without the associated severe clinical signs [33] or associated morbidity and mortality [27]. A relatively high prevalence of infection is present in the Taï cercopithecids.

Trichuris sp. are parasitic nematodes that infect the ceca and colons of animal hosts and cause trichuriasis similar to that of humans. Trichuris sp. has a simple and direct life cycle. Similarities of Trichuris sp. infection are found in non-human primates and humans suggesting significant zoonotic transmission. However, many differences in egg morphometrics have been detected in non-human primates and the monkey-derived whipworm is a separate species from that found in humans [36]. Unfortunately, coprological analyses are inconclusive. A comprehensive study of genetic diversity is necessary to make a confident distinction between species. The Colobus species in the present study exhibited a very high prevalence, such as that found in primates of Boabeng-Fiema, Ghana, and Kibale Forest, Uganda [19, 67].

Anatrichosoma species are an unusual group of zoonotic trichuroid nematodes. Their occurrence is so rare that knowledge is limited and diagnosis uncommon [51, 53]. These rare nematodes have been identified in primates in Africa and Asia, but their life cycle remains unknown. Infections are normally recognized through the direct observation of adult worms from biopsy rather than through the recovery of eggs. Worms normally reside in the squamous epithelium of the nasal cavities $[2,38,53]$. Eggs are sloughed off and are usually swallowed where they are passed into the feces [53]. Eggs of Anatrichosoma in fecal samples were recently reported in chimpanzees and vervets of Tanzania's Rubondo Island [57, 59]. In the present study, they were found in Cercocebus and C. petaurista which, to our knowledge, is the first report of Anatrichosoma sp. in Cercocebus and Cercopithecus species and the first in any free-ranging West African primate.

Capillariids are closely related to Trichuris and Trichinella species; all are members of the superfamily Trichinelloidea. Several species of the family Capillariidae are known to infect primates including humans: these are Calodium hepaticum, Eucoleus aerophilus, Paracapillaria philippinensis, Aonchotheca brochieri, and A. annulosa [14, 29, 47, 48]. Other species of Capillariids, such as those found in Macaca, were undetermined [29]. In the present study, we describe two distinct capillariids based on egg size and morphology. Study of adult worms combined with molecular analysis would provide for the determination of genus and species.

Hookworms are parasitic nematodes, belonging to the family Ancylostomatidae. They live in the small intestine of their hosts, which may be mammals such as humans and non-human primates $[46,54]$. Infection with hookworms is due to the penetration of larvae (L3) through the skin or by direct ingestion of dirt (pica) or fresh vegetables containing filariform larvae. Infection via skin entry can cause skin inflammation and intestinal blood loss at the site of adult parasite intestinal attachment. The life cycle of hookworms is direct [25, 62]. Hookworms have been reported in several populations of free-ranging African primates [7, 20, 57, 58]. Differentiating the various hookworm species by morphological analysis of the eggs is difficult microscopically; however, the hookworms present in our samples appear to represent Necator sp. and/or Ancylostoma sp.

Ternidens spp. are widespread in African non-human primates (e.g., baboons and vervet monkeys) and are typically found in the large intestine of primates. They cause anemia and the development of nodules in the intestinal wall similar to those of Oesophagostomum spp. Because of the similarity between Ternidens eggs and those of hookworms and related species, microscopy diagnosis error is probably common. Thus, for identification purposes, measurement of egg size is important for differentiating hookworms and T. deminutus: hookworm eggs are approximately $70 \mu \mathrm{m} \times 40 \mu \mathrm{m}$ while those of $T$. deminutus are approximately $84 \mu \mathrm{m} \times 51 \mu \mathrm{m}$ [22]. Ternidens sp. have been found in Cercopithecus species $[4,63]$, such as those present in Taï National Park. A comprehensive molecular study is needed to more firmly establish species differences.

Trichostrongylus spp. are known to infect humans, wild animals, livestock and, especially, herbivorous animals. Primates can become infected due to environmental contamination by ruminants [49]. This study recorded Trichostrongylus only in $C$. diana and $C$. verus with low prevalence, in contrast to that found in baboons [52].

Non-human primates are known to be the major hosts of Strongyloides stercoralis and, especially, S. fuelleborni. Monkeys become infected by eating eggs or via skin penetration by third-stage infective larvae [17, 68]. Taï forest primates were infected by Strongyloides stercoralis and Strongyloides sp. However, Strongyloides sp. was predominant.

Chitwoodspirura sp. was described from adult worms collected in the stomach of gorillas [10]. The complements to the morphology of this species (worms and eggs) were provided later [50]. Chitwoodspirura is a spirurid nematode that has an arthropod intermediate host. The thick-shelled nature of the egg passed in the feces would suggest that the intermediate host is likely to be a coprophagous arthropod of some type that becomes infected by ingesting the embryonated egg. There is no known information about the life cycle of Chitwoodspirura sp. Eggs of Chitwoodspirura sp. were recorded recently in red 
colobus monkeys and in red-tailed monkeys in Tanzania [30]. At Taï, only C. petaurista were infected by Chitwoodspirura sp. and this is the first identified case in any West African primate.

The spirurid nematode Protospirura muricola is a parasite of African rodents. The life cycle requires an intermediate host and a synanthropic rat final host where it seems to be nonpathogenic [64]. In some primates, pathogenicity was variable and remains unknown in chimpanzees. Protospirura muricola has been reported in red-tailed monkeys and red colobus monkeys at Mahale National Park [30]. Egg morphology found in samples from the Taï monkeys matched descriptions of eggs found in Tanzanian chimpanzees [59].

Dicrocoelium spp. use insects (ants) as intermediate hosts [70]. Monkeys become infected by ingesting infected ants or food contaminated by ants. Dicrocoelium spp. (Trematoda, Dicrocoeliidae) live mainly in the bile ducts and gall bladders of domestic and wild ruminants and occasionally parasitize primates including humans. We have not yet recorded Dicrocoelium sp. in any Cercopithecus species from Taï; however, prevalence in the sooty mangabey and red colobus was similar to that found in Kenya's Tana River primates [39].

\section{Conclusion}

Our study provides baseline data on the gastrointestinal parasites in populations of free-ranging, forest-dwelling West African monkeys. More specifically, we provide the first parasite information on the cercopithecid monkey populations within Côte d'Ivoire's Taï National Park. During our study, we recorded 23 gastrointestinal parasites with relatively high prevalence. No cestode species were recovered. Only coprological analyses based on morphological and morphometric examination were performed. Some identifications were made at the family or genus level; however, several parasites represent zoonoses. Further assessment of these via molecular analysis is underway which will allow us to not only examine incidences of cross-infection among these primates, but also evaluate the potential presence of zoonoses in this region. In addition to more thoroughly documenting the prevalence and diversity of parasite species, future research will facilitate better identification and understanding of the correlations between parasitism and diet, social behavior, home ranges, and group size in these and other primate taxa.

Acknowledgements. We thank the following agencies for permission to conduct fieldwork in the Taï Forest: Ministère de l'Enseignement Supérieur et de la Recherche Scientifique, and the Ministère de l'Environnement et des Eaux et Forêts, Office Ivoirien des Parcs et Réserves (OIPR). We thank the assistants of the Taï Monkey Project and its field coordinator Dr. Anderson Bitty. We are grateful to the Centre Suisse de Recherches Scientifiques en Côte d'Ivoire and the Plateau Technique de Microbiologie des Hôpitaux Universitaires de Strasbourg (HUS) for technical assistance. Thanks are also due to Drs. Nathan Tian Bi and Jean Coulibaly for statistical assistance. This work was financially supported by the Programme d'Appui Stratégique à la Recherche Scientifique (PASRES, Project No. 48) and US National Science Foundation (NSF) 0921770 and 0922429.

\section{References}

1. Alfellani MA, Jacob AS, Perea NO, Krecek RC, Taner-Mulla D, Verweij JJ, Levecke B, Tannich E, Clark CG, Stensvold CR. 2013. Diversity and distribution of Blastocystis sp. subtypes in nonhuman primates. Parasitology, 140, 966-971.

2. Allen AM. 1960. Occurrence of the nematode, Anatrichosoma cutaneum, in the nasal mucosae of Macaca mulatta monkeys. American Journal of Veterinary Research, 21, 389-392.

3. Altizer S, Nunn CL, Lindenfors P. 2007. Do threatened hosts have fewer parasites? A comparative study in primates. Journal of Animal Ecology, 76, 304-314.

4. Appleton CC, Brain C. 1995. Gastro-intestinal parasites of Papio cynocephalus ursinus living in the central Namib desert, Namibia. African Journal of Ecology, 33, 257-265.

5. Bakarr MI, Gbakima AA, Bah Z. 1991. Intestinal helminth parasites in free-living monkeys from a West African rainforest. African Journal of Ecology, 29, 170-172.

6. Belova LM, Krylov MV. 1998. The distribution of Blastocystis according to different systematic groups of hosts. Parazitologiia, 32, 268-276.

7. Bezjian M, Gillespie TR, Chapman CA, Greiner EC. 2008. Coprologic evidence of gastrointestinal helminths of forest baboons, Papio anubis, in Kibale National Park, Uganda. Journal of Wildlife Diseases, 44, 878-887.

8. Blagg W, Schloegel EL, Mansour NS, Khalaf GI. 1955. A new concentration technic for the demonstration of protozoa and helminth eggs in feces. American Journal of Tropical Medicine and Hygiene, 4, 23-28.

9. Boreham PF, Stenzel DJ. 1993. Blastocystis in humans and animals: morphology, biology, and epizootiology. Advances in Parasitology, 32, 1-70.

10. Chabaud AG, Rousselot R. 1956. Un nouveau spiruride parasite du gorille Chitwoodspirura wehri n.g., n. sp. Bulletin de la Société de Pathologie Exotique et de ses Filiales, 49, 467-472.

11. Chapman CA, Gillespie TR, Speirs ML. 2005. Parasite prevalence and richness in sympatric colobines: effects of host density. American Journal of Primatology, 67, 259-266.

12. Clark CG, van der Giezen M, Alfellani MA, Stensvold CR. 2013. Recent developments in Blastocystis research. Advances in Parasitology, 82, 1-32.

13. International Conservation. 2001. De la forêt à la mer: les liens de biodiversité de la Guinée au Togo. Conservation International: Washington. p. 78.

14. Cross JH. 1992. Intestinal capillariasis. Clinical Microbiology Reviews, 5, 120-129.

15. Erdman DD. 1981. Clinical comparison of ethyl acetate and diethyl ether in the formalin-ether sedimentation technique. Journal of Clinical Microbiology, 14, 483-485.

16. Formenty P, Boesch C, Wyers M, Steiner C, Donati F, Dind F, Walker F, Le Guenno B. 1999. Ebola virus outbreak among wild chimpanzees living in a rain forest of Côte d'Ivoire. Journal of Infectious Diseases, 179, 120-126.

17. Gillespie TR, Chapman CA. 2006. Prediction of parasite infection dynamics in primate metapopulations based on attributes of forest fragmentation. Conservation biology, 20, 441-448.

18. Gillespie TR, Greiner EC, Chapman CA. 2004. Gastrointestinal parasites of the guenons of western Uganda. Journal of Parasitology, 90, 1356-1360. 
19. Gillespie TR, Greiner EC, Chapman CA. 2005. Gastrointestinal parasites of the colobus monkeys of Uganda. Journal of Parasitology, 91, 569-573.

20. Gillespie TR, Lonsdorf EV, Canfield EP, Meyer DJ, Nadler Y, Raphael J, Pusey AE, Pond J, Pauley J, Mlengeya T, Travis DA. 2010. Demographic and ecological effects on patterns of parasitism in eastern chimpanzees (Pan troglodytes schweinfurthii) in Gombe National Park, Tanzania. American Journal of Physical Anthropology, 143, 534-544.

21. Gogarten JF, Akoua-Koffi C, Calvignac-Spencer S, Leendertz SJ, Weiss S, Couacy-Hymann E, Koné I, Peeters M, Wittig RM, Boesch C, Hahn BH, Leendertz FH. 2014. The ecology of primate retroviruses - an assessment of 12 years of retroviral studies in the Taï national park area, Côte d'Ivoire. Virology, 460-461, 147-153.

22. Goldsmid JM. 1968. The differentiation of Ternidens deminutus and hookworm ova in human infections. Transactions of the Royal Society of Tropical Medicine and Hygiene, 62, 109-116.

23. Graczyk TK, Grimes BH, Knight R, Da Silva AJ, Pieniazek NJ, Veal DA. 2003. Detection of Cryptosporidium parvum and Giardia lamblia carried by synanthropic flies by combined fluorescent in situ hybridization and a monoclonal antibody. American Journal of Tropical Medicine and Hygiene, 68, 228-232.

24. Hasegawa H, Huffman MA, Chapman CA. 2009. Useful diagnostic references and images of protozoans, helminths, and nematodes commonly found in wild primates, in Primate Parasite Ecology, Huffman MA, Chapman CA, Editors. Cambridge University Press: Cambridge. p. 507-513.

25. Hoagland KE, Schad GA. 1978. Necator americanus and Ancylostoma duodenale: life history parameters and epidemiological implications of two sympatric hookworms of humans. Experimental Parasitology, 44, 36-49.

26. Howells ME, Pruetz J, Gillespie TR. 2011. Patterns of gastrointestinal parasites and commensals as an index of population and ecosystem health: the case of sympatric western chimpanzees (Pan troglodytes verus) and guinea baboons (Papio hamadryas papio) at Fongoli, Senegal. American Journal of Primatology, 73, 173-179.

27. Huffman MA, Gotoh S, Turner LA, Hamai M, Yoshida K. 1997. Seasonal trends in intestinal nematode infection and medicinal plant use among chimpanzees in the Mahale Mountains, Tanzania. Primates, 38, 111-125.

28. Jessee MT, Schilling PW, Stunkard JA. 1970. Identification of intestinal helminth eggs in old world primates. Laboratory Animal Care, 20, 83-87.

29. Justine JL. 1988. Capillaria brochieri n. sp. (Nematoda: Capillariinae) parasite intestinal du chimpanzé Pan paniscus au Zaire. Annales de Parasitologie Humaine et Comparée, 63, $420-438$.

30. Kooriyama T, Hasegawa H, Shimozuru M, Tsubota T, Nishida T, Iwaki T. 2012. Parasitology of five primates in Mahale Mountains National Park, Tanzania. Primates, 53, 365-375.

31. Kouassi WYR. 2008. Relation et communication interspécifique entre trois espèces de Cercopithèques dans le Parc National de Taï. Mémoire de DEA, Université de Cocody Abidjan: Côte d'Ivoire.

32. Köndgen S, Leider M, Lankester F, Bethe A, Lübke-Becker A, Leendertz FH, Ewers C. 2011. Pasteurella multocida involved in respiratory disease of wild chimpanzees. PLoS One, 6, e24236.
33. Krief S, Jamart A, Mahe S, Leendertz FH, Matz-Rensing K, Crespeau F, Bain O, Guillot J. 2008. Clinical and pathologic manifestation of oesophagostomosis in African great apes: does self-medication in wild apes influence disease progression? Journal of Medical Primatology, 37, 188-195.

34. Leendertz F, Ellerbock H, Boesch C, Couacy-Hymann E, MätzRensing K, Hakenback R, Bergmann C, Abaza P, Junglen S, Moebius Y, Vigilant L, Formenty P, Pauli G. 2004. Anthrax kills wild chimpanzees in a tropical rainforest. Nature, 430, 451-452.

35. Levine JA, Estevez EG. 1983. Method for concentration of parasites from small amounts of feces. Journal of Clinical Microbiology, 18, 786-788.

36. Liu GH, Gasser RB, Nejsum P, Wang Y, Chen Q, Song HQ, Zhu XQ. 2013. Mitochondrial and nuclear ribosomal DNA evidence supports the existence of a new Trichuris species in the endangered françois' leaf-monkey. PLoS One, 8, e66249.

37. Locatelli S, Liegeois F, Lafay B, Roeder AD, Bruford MW, Formenty P, Noe R, Delaporte E, Peeters M. 2008. Prevalence and genetic diversity of simian immunodeficiency virus infection in wild-living red colobus monkeys (Piliocolobus badius badius) from the Taï forest, Cote d'Ivoire SIVwrc in wild-living western red colobus monkeys. Infection, Genetics and Evolution, 8, 1-14.

38. Long GG, Lichtenfels JR, Stookey JL. 1976. Anatrichosoma cynamolgi (Nematoda: Trichinellida) in rhesus monkeys, Macaca mulatta. Journal of Parasitology, 62, 111-115.

39. Mbora DN, McPeek MA. 2009. Host density and human activities mediate increased parasite prevalence and richness in primates threatened by habitat loss and fragmentation. Journal of Animal Ecology, 78, 210-218.

40. Mbora DN, Munene E. 2006. Gastrointestinal parasites of critically endangered primates endemic to Tana River, Kenya: Tana River red colobus (Procolobus rufomitratus) and crested mangabey (Cercocebus galeritus). Journal of Parasitology, 92, 928-932.

41. Mbora DN, Wieczkowski J, Munene E. 2009. Links between habitat degradation, and social group size, ranging, fecundity, and parasite prevalence in the Tana River mangabey (Cercocebus galeritus). American Journal of Physical Anthropology, 140, 562-571.

42. McGraw WS. 1996. Cercopithecid locomotion, support use, and support availability in the Taï Forest, Ivory Coast. American Journal of Physical Anthropology, 100, 507-522.

43. McGraw WS. 1998. Comparative locomotion and habitat use of six monkeys in the Taï Forest, Ivory Coast. American Journal of Physical Anthropology, 105, 493-510.

44. McGraw WS, Zuberbuhler K, Noe R. 2007. Monkeys of the Tai forest, an African primate community. Cambridge University Press.

45. McGrew WC, Tutin CEG, Collins DA, SK File. 1989. Intestinal parasites of sympatric Pan troglodytes and Papio spp. at two sites: Gombe (Tanzania) and Mt. Assirik (Senegal). American Journal of Primatology, 17, 147-155.

46. Miller TA. 1979. Hookworm infection in man. Advances in Parasitology, 17, 315-384.

47. Moravec F. 2001. Redescription and systematic status of Capillaria philippinensis, an intestinal parasite of human beings. Journal of Parasitology, 87, 161-164.

48. Moravec F, Baruš V. 1991. Systematic status of Thominx platyrrhinorum Barus, 1961 (Nematoda: Capillariidae). Folia Parasitologica, 38, 155-162. 
49. Munene E, Otsyula M, Mbaabu DA, Mutahi WT, Muriuki SM, Muchemi GM. 1998. Helminth and protozoan gastrointestinal tract parasites in captive and wild-trapped African non-human primates. Veterinary Parasitology, 78, 195-201.

50. Noda R, Yamada H. 1964. On two species of nematodes, Necator gorillae sp. nov. (Ancylostomidae) and Chitwoodspirura wehri Chabaud and Rousselot, 1956 (Spiruridae), from gorilla. Bulletin of the University of Osaka Prefecture, Series B: Agriculture and Biology, 15, 175-180.

51. Nunez FA. 2010. Trichuris, Capillaria or Anatrichosoma? [corrected]. Parasitology International, 59, 303

52. Ocaido M, Dranzoa C, Cheli P. 2003. Gastrointestinal parasites of baboons (Papio anubis) interacting with humans in West Bugwe Forest Reserve, Uganda. African Journal of Ecology, 41, 356-359.

53. Orihel TC. 1970. Anatrichosomiasis in African monkeys. Journal of Parasitology, 56, 982-985.

54. Orihel TC. 1971. Necator americanus infection in primates. Journal of Parasitology, 57, 117-121.

55. Parkar U, Traub RJ, Vitali S, Elliot A, Levecke B, Robertson I, Geurden T, Steele J, Drake B, Thompson RC. 2010. Molecular characterization of Blastocystis isolates from zoo animals and their animal-keepers. Veterinary Parasitology, 169, 8-17.

56. Pedersen AB, Altizer S, Poss M, Cunningham AA, Nunn CL. 2005. Patterns of host specificity and transmission among parasites of wild primates. International Journal for Parasitology, 35, 647-657.

57. Petrášová J, Modrý D, Huffman MA, Mapua MI, Bobáková L, Mazoch V, Singh J, Kaur T, Petrželková KJ. 2010. Gastrointestinal parasites of indigenous and introduced primate species of Rubondo Island National Park, Tanzania. International Journal of Primatology, 31, 920-936.

58. Petrzelkova KJ, Hasegawa H, Appleton CC, Huffman MA, Archer CE, Moscovice LR, Mapua MI, Singh J, Kaur T. 2010. Gastrointestinal parasites of the chimpanzee population introduced onto Rubondo Island National Park, Tanzania. American Journal of Primatology, 72, 307-316.

59. Petrzelkova KJ, Hasegawa H, Moscovice LR, Kaur T, Issa M, Huffman MA. 2006. Parasitic nematodes in the chimpanzee population on Rubondo Island, Tanzania. International Journal of Primatology, 27, 767-777.

60. Ryan SJ, Brashares JC, Walsh C, Milbers K, Kilroy C, Chapman CA. 2012. A survey of gastrointestinal parasites of olive baboons (Papio anubis) in human settlement areas of Mole National Park, Ghana. Journal of Parasitology, 98, 885-888.

61. Salzer JS, Rwego IB, Goldberg TL, Kuhlenschmidt MS, Gillespie TR. 2007. Giardia sp. and Cryptosporidium sp. infections in primates in fragmented and undisturbed forest in western Uganda. Journal of Parasitology, 93, 439-440.

62. Schad GA, Banwell JG. 1984. Hookworms, in Tropical and geographical medicine. Warren KS, Mahmoud AAF, Editors. McGraw-Hill Book Co.: New York. p. 359-372.

63. Schindler AR, de Gruijter JM, Polderman AM, Gasser RB. 2005. Definition of genetic markers in nuclear ribosomal DNA for a neglected parasite of primates, Ternidens deminutus (Nematoda: Strongylida) - diagnostic and epidemiological implications. Parasitology, 131, 539-546.

64. Smales LR, Harris PD, Behnke JM. 2009. A redescription of Protospirura muricola Gedoelst, 1916 (Nematoda: Spiruridae), a parasite of murid rodents. Systematic Parasitology, 72, $15-26$.

65. Stensvold CR, Alfellani MA, Nørskov-Lauritsen S, Prip K, Victory EL, Maddox C, Nielsen HV, Clark CG. 2009. Subtype distribution of Blastocystis isolates from synanthropic and zoo animals and identification of a new subtype. International Journal for Parasitology, 39, 473-479.

66. Stenzel DJ, Boreham PF. 1996. Blastocystis hominis revisited Clinical Microbiology Reviews, 9, 563-584.

67. Teichroeb JA, Kutz SJ, Parkar U, Thompson RC, Sicotte P. 2009. Ecology of the gastrointestinal parasites of Colobus vellerosus at Boabeng-Fiema, Ghana: possible anthropozoonotic transmission. American journal of Physical Anthropology, 140, 498-507.

68. Viney ME, Lok JB. 2007. Strongyloides spp., in WormBook: the online review of C. elegans Biology. p. 1-15.

69. Wanert F, Vidal S. 2006. Maladies, parasites et agents infectieux des Primates non Humains. Sciences et Technique de l'Animal de Laboratoire $1^{\mathrm{er}}$ trimestre, 1, 59-65.

70. Yamashita J. 1963. Ecological relationships between parasites and primates. Primates, 4, 1-96.

71. Yoshikawa $\mathrm{H}$, Morimoto $\mathrm{K}, \mathrm{Wu} \mathrm{Z}$, Singh $\mathrm{M}$, Hashimoto $\mathrm{T}$. 2004. Problems in speciation in the genus Blastocystis. Trends in Parasitology, 20, 251-255.

72. Yoshikawa H, Wu Z, Howe J, Hashimoto T, Geok-Choo N, Tan KS. 2007. Ultrastructural and phylogenetic studies on Blastocystis isolates from cockroaches. Journal of Eukaryotic Microbiology, 54, 33-37.

73. Young KH, Bullock SL, Melvin DM, Spruill CL. 1979. Ethyl acetate as a substitute for diethyl ether in the formalin-ether sedimentation technique. Journal of Clinical Microbiology, 10, 852-853.

74. Zierdt CH. 1991. Blastocystis hominis - past and future. Clinical Microbiology Reviews, 4, 61-79. 
Cite this article as: Kouassi RYW, McGraw SW, Yao PK, Abou-Bacar A, Brunet J, Pesson B, Bonfoh B, N'goran EK \& Candolfi E: Diversity and prevalence of gastrointestinal parasites in seven non-human primates of the Taï National Park, Côte d'Ivoire. Parasite, 2015, 22, 1 .

\section{(0) PARASTE}

An international open-access, peer-reviewed, online journal publishing high quality papers on all aspects of human and animal parasitology

Reviews, articles and short notes may be submitted. Fields include, but are not limited to: general, medical and veterinary parasitology; morphology, including ultrastructure; parasite systematics, including entomology, acarology, helminthology and protistology, and molecular analyses; molecular biology and biochemistry; immunology of parasitic diseases; host-parasite relationships; ecology and life history of parasites; epidemiology; therapeutics; new diagnostic tools.

All papers in Parasite are published in English. Manuscripts should have a broad interest and must not have been published or submitted elsewhere. No limit is imposed on the length of manuscripts.

Parasite (open-access) continues Parasite (print and online editions, 1994-2012) and Annales de Parasitologie Humaine et Comparée (1923-1993) and is the official journal of the Société Française de Parasitologie. 